\title{
Reforming Pensions: Principles and Policy Choices $^{1}$ \\ Reforma dichodového systému - zásady a politická rozhodnutí
}

\section{NICHOLAS BARR}

\section{Good morning everybody}

It is good, as always, to be back in Prague, and a great pleasure to take part in the award of the Professor Vencovský prize. On a personal note, it was twenty years today that I first flew to this part of the world as a member of a World Bank mission to help to reform social safety nets, so I share with many of you the twentieth anniversary feeling of this month.

\section{The backdrop}

Social Europe - problems and perspectives. There is much that we can talk about. I shall concentrate on an area with which I have been involved for many years - pension reform. I will start with some background matters, then set out the problems facing Europe and other countries, then look at different types of pension arrangement that offer potential solutions to those problems and then, if I have time, offer a few brief concluding thoughts.

My discussion draws heavily on collaboration with Peter Diamond from MIT (Barr and Diamond, 2008, 2009, 2010), which grew out of work we did five years ago, advising the government of China on pension reform, Much of what we wrote then was not used in our report, so we thought we would turn it into a quick, short book - and failed on both counts, since it took four years till a rather long book (2008) was published - so long that Oxford University Press have just published a shorter version (2010). Though, the books were written before the economic crisis, what they say remains relevant, perhaps even more relevant in the face of economic problems.

Four objectives of pension systems stand out. For the individual, pensions exist, first, to provide consumption smoothing, that is, to re-distribute from ones productive middle years to ones retired self. A second objective is insurance against risk, in the case of pensions, mainly the risk of outliving ones pension savings; thus annuities are part of the insurance objective. Public policy has additional objectives, including poverty relief, and in many countries also re-distribution.

With that by way of background, let me talk about five major messages from the book.

1 This is a lightly edited text of a lecture delivered at the Czech National Bank on 27 November 2009.

2 London School of Economics and Political Science, Houghton Street, London WC2A 2AE; N.Barr@lse.ac.uk 
IT AIN'T THE BABY BOOM. The first message is that the problems we face in paying for pensions are not caused by the baby boom. The real causes are very long run and very well know trends. People are living longer, having fewer children, and tending to retire earlier. Those three factors are much more important than shorter run trends like the baby boom.

Figure 1 shows projected age pyramids in 2050 for three countries. The bottom one is the United States, which had a baby boom, the top one is China, which had, and still largely has, a one child policy, and the middle one is India, which has neither. Figure 1 illustrates that there are aging problems in three very different types of society, showing that the main drivers are greater life expectancy and declining fertility.

Figure 1: Age pyramids 2050, China, India, USA
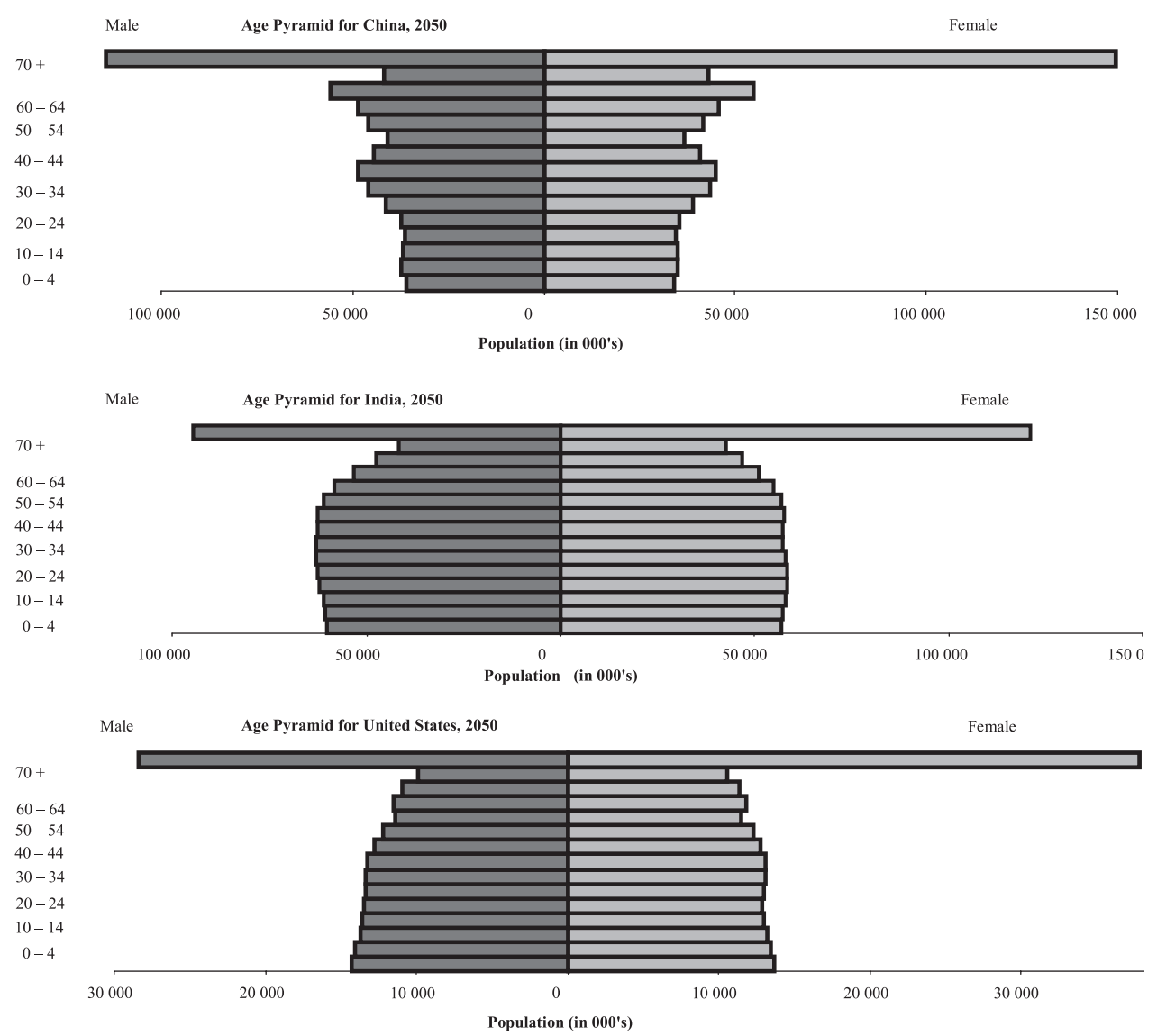

Source: Barr and Diamond, 2008, Figure 1.5.

IT IS NOT A CRISIS. I tell my students that they have as much freedom to express their personal opinions as I do. But I tell them that there is one exception: if they use the term, "ageing problem", they fail. There is not an ageing problem. The great triumph of the twentieth century is that people are living longer healthy lives. This is good news. The problem 
is not that people are living too long, but that they are retiring too soon. Figure 2 shows data for the United Kingdom. The top bar shows the story of a man who retired in 1950 . He left school at the age of fourteen, worked until the then average retirement age of 67 , thus contributing for 53 years, and then retired with eleven years of remaining life. A man who retired a few years ago left school at sixteen, contributed for 48 years and retired at the then average retirement age of 63 , at which point he had 20 years of retirement. Thus the man who retired in 1950 contributed for five years for each year of retirement, the man who retired in 2004, for only two and a half years. This makes the point that we are living longer, which is good news, but has the important implication that we need to work longer.

FUNDED PENSIONS ARE NOT A PANACEA. Funded pensions are paid from an accumulated fund built up over a period of years out of the contributions of its members, whereas pay as you go pensions are paid, usually by the state, out of current tax revenues. The World Bank has advocated funded private pensions, arguing that they promote economic growth, increase coverage, and improve old age security. Barr and Diamond (2008) explain that there are significant errors in the World Bank's analysis. That is not an argument against private pensions. If there are journalists here who say, "Barr attacks private pensions" they are mistaken. I am not attacking private pensions. I am attacking claims for private, funded pensions that do not stand up. The argument in the book is that funded pensions may be a useful part of a pension system, but that will depend on the economic circumstances of a country; there are sound economic analytical principles that explain when private pensions will be helpful and when not. Funded pensions may be part of a good policy but not always or everywhere.

Figure 2: Working life and retirement

\section{Life course, men retiring in 1950 and 2004}

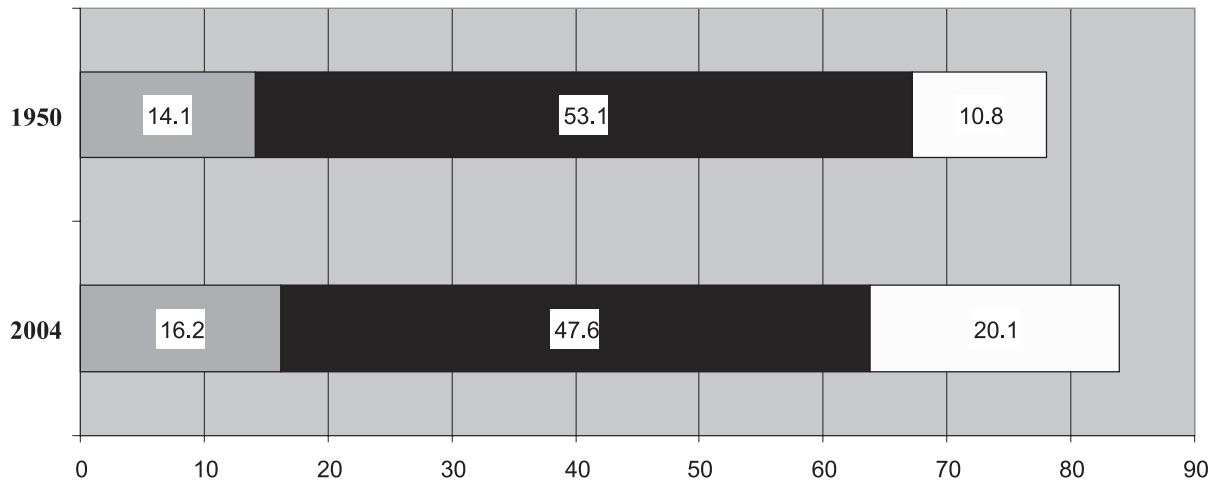

Education, work and retirement

POLICY SHOULD TAKE ACCOUNT OF THE MULTIPLE OBJECTIVES OF PENSIONS. AS discussed, pensions have multiple objectives: poverty relief, consumption smoothing, insurance and re-distribution. It is mistaken to be obsessed with one part of the pension system; sound analysis considers the system as a whole. 
There is no single best pension system. The reason is straightforward. There are different objectives, and countries face different constraints, including fiscal constraints and institutional capacity constraints. The empirical value of behavioural parameters will also vary, for example the sensitivity of work effort to any increase in taxes, or the sensitivity of saving to changes in the interest rate. And the shape of the income distribution will be different in different countries. Thus there is no single best pension system, because the objectives will differ from country to country and the constraints will differ; and if the objectives differ and the constraints differ then the optimum will differ.

The point is illustrated in a political context by the following quote.

"Designing a White House staff, like designing an aircraft, involves trade-offs. If you want speed of decision, you must narrow the number of those involved in the decision - thus sacrificing breadth of information and depth of debate. If you demand single-minded devotion to yourself, you will probably choose people who lack other career options - which is to say, people who are less than supremely able. If you want to recruit the best and the brightest, you will have little choice but to end up with people of strong wills, big egos and intense principles, who may put their beliefs before your interests. The problem of designing an effective political organisation cannot be solved, it can only be finessed." David Frum, "They stood by their man," Prospect Magazine, Issue 148, July 2008, pp. 12 - 13.

\section{Social Europe: What are the problems?}

I will talk about two problems. One, which I have already mentioned, is how to pay for pensions; the other is how to make pensions portable internationally as citizens of the EU work in different countries.

\subsection{Paying for pensions}

Table 1 gives figures on public pension spending in a range of countries in 2000, and projected spending in 2030 and 2050. Greece is currently spending around $12.6 \%$ of GDP on pensions and, if nothing is done, by 2050 will be spending $25 \%$ of GDP on pensions, which is totally unsustainable. Earlier this morning we listened to the Governor of the National Bank and the Finance Minister, and I recognize that there is a problem paying for pensions in the Czech Republic; but the good news for the Finance Minister is that the situation in other countries is even in worse, Greece being a particular case in point. So paying for pensions is not just a Czech problem but a problem almost across Europe. One of the few countries that do not have this problem is the United Kingdom, and our solution is a shameful one, we have solved our pension problems by reducing pensions so that they no longer adequately fulfil their poverty relief function.

In facing these problems, there are only four ways ahead.

- $\quad$ Reduce pension spending by paying a lower monthly pension;

- Later retirement on the same pension: this option reduces pension spending not by reducing living standards in retirement but by reducing the duration of retirement;

- Higher contributions; 
- Increased national output: if national output is higher, there are more resources to pay for pensions.

Table 1: Current and projected public pension spending, various countries, $\%$ of GDP

\begin{tabular}{|l|l|l|l|} 
& $\mathbf{2 0 0 0}$ & $\mathbf{2 0 3 0}$ & $\mathbf{2 0 5 0}$ \\
\hline Denmark & 10.5 & 14.5 & 13.3 \\
\hline France & 12.1 & 16.0 & n. a. \\
\hline Germany & 11.8 & 15.5 & 16.9 \\
\hline Greece & 12.6 & 19.6 & 24.8 \\
\hline Netherlands & 7.9 & 13.1 & 13.6 \\
\hline Sweden & 9.0 & 11.4 & 10.7 \\
\hline UK & 5.5 & 5.2 & 4.4 \\
\hline
\end{tabular}

Source: UK Pensions Commission (2004, Table D2).

When witnesses appeared before the excellent UK Pensions Commission (2004, 2005), saying "here is the solution", Adair Turner, the Commission's Chairman, would say, "Through which one or more of those four channels does your solution work? If your solution does not work through at least one, it is not a solution." These are the only options, and of those in many ways the most attractive is the last - policies to increase output.

So, what are the policies to increase output? The World Bank argues that funded pensions will increase savings and hence output. That may or may not be true. It may be true in some countries, but is not necessarily true. And even if it is true, that is only one of a range of ways of increasing output.

In principle there are two ways to raise output: increasing the productivity of each individual worker, or increasing the number of workers from each age cohort.

- The way to increase the productivity of each worker is through higher saving, which leads to more and better capital equipment; another way to raise productivity is through higher investment in human capital. Thus growth can derive not only from investment in physical capital but also in human capital, including the human capital of older workers.

- It is possible to increase the number of workers from each age cohort through higher labour force participation at all ages, including higher participation by older workers; through a higher age of retirement; and by importing labour, either directly through immigration or indirectly by exporting capital to countries with younger populations.

- Thus there is a range of ways of paying for pensions and a range of ways of increasing output. My message to government is that all these policies are important for increasing output and all should be pursued. In many ways the one that is closest to my heart is investment in human capital. Skills are enormously important to addressing the problems of Social Europe. 


\subsection{Making pensions portable}

Alongside paying for pensions is a parallel problem of making pensions portable. Over the course of your careers, particularly the younger people in the audience are likely to work in several EU countries. But national pension systems differ. Some are contributory, like the United Kingdom, France or Germany, others have non-contributory elements like the Netherlands. Pensions differ in the number of years of contributions necessary to qualify for a full pension. The pension formula is different in each country. The role of private pensions is very different in different countries. The problem that causes is that workers who move across countries may end up with very little pension. I have a colleague at the London School of Economics who is a good European: he talks about six European languages and his written English is better then that of most of my English colleagues. He has had an academic career in several European countries and I am exaggerating only slightly, when I say that he has a pension in none, because he never worked long enough for his pension rights to become vested. The problem that non-portability of this type causes is the resulting impediment to labour mobility.

Labour mobility matters because it is necessary for efficiency in a modern economy; it is possible also to argue that labour mobility is an important element in human rights. If citizens of the Czech Republic are constrained from working in France or Germany because of pension arrangements, that is a serious problem, and not one with an obvious solution. It is a question I set for my graduate seminar each year in the hope that one of the students will have a brilliant idea - so far with no success. But the problem is one to which politicians and policy makers should be paying more attention than they do.

\section{What pension arrangements?}

Though I have argued that there is no single best pension system, I turn now to four policy directions that are not perfect for every country but are interesting. Some are new, so that it is important that policy makers in the Czech Republic and other European countries are aware of them.

\subsection{Avoiding elderly poverty}

I want to talk first about the idea of a non-contributory basic pension, that is, a tax-financed pension paid at a flat rate on the basis of age and residence rather than on the basis of contributions. The contributory principle assumed that workers would have a long, stable history of employment, so that coverage would grow. But that has not happened; and the reason is easy to explain. Social policy in 1950, at the time when contributory systems were being reinforced after the Second World War, was based on a series of assumptions: independent nation states; full-time employment for the whole of a person's career; limited international mobility; a stable nuclear family, where people got married, stayed married, the husband earned the money, and the wife looked after the children; and skills that would last for a lifetime. None of those assumptions were strictly accurate even in 1950 , but they were accurate enough for good social policy.

None of those assumptions are true any longer. Two in particular stand out. First is the changing nature of work. People's relationship with the labour market today is much more 
fluid than in 1950. People are not necessarily in full time employment for the whole of their career; people have full time employment, spells of self employment, spells of parttime work, and spells outside the labour force. Thus people will have a less complete record of contributions than in the past; the contributory principle no longer provides the coverage it once did.

The second major change is that family structures have become more fluid: the association between marriage and children is weaker and divorce more common than used to be the case. Thus basing a woman's entitlement to pension on a husband's contributions is no longer feasible. That approach may or may not have been a good idea in 1950 but at least it worked; today it no longer works.

Thus the argument for non-contributory pensions is that they strengthen poverty relief. They can cover everybody; and they can pay a pension high enough to provide genuine poverty alleviation. They also have advantages in terms of gender balance, since it is typically women who have the most fragmented contributions records. There are other advantages: the incentives to work effort from a non-contributory pension are better than those of income tested poverty relief; the benefit is fairly well targeted, because age is a useful indicator of poverty; and non-contributory pensions can be made internationally portable more easily than other formulae.

The idea of a non-contributory pension makes Ministers of Labour and Social Policy happy but cause fear and trembling among Ministers of Finance, who worry about the fiscal sustainability of such an arrangement. The question is how to have a non-contributory pension that is affordable. There is a range of instruments for doing so, notably (a) the size of the monthly pension and (b) the age at which the pension is first paid. If policy makers wish to pay a non-contributory pension at a rate that makes a genuine contribution to poverty relief without causing fiscal problems one option is to pay the benefit only from the age of seventy, lowering the age of eligibility as fiscal capacity increases.

The UK, where workers need over forty years of contributions to get a full basic state pension, illustrates the problems of coverage. Only $80 \%$ of men have a full contributions record and only $35 \%$ of women. This problem is not because of difficulties in collecting contributions, which the UK does well, but results from the inherent nature of the contributory principle in the context of today's labour markets and family structures. Thus it is not surprising that several OECD countries have non-contributory pensions, including the Netherlands, New Zealand, Australia, Canada and, since 2008, Chile.

\subsection{Redefining retirement}

A second strategic policy direction is to re-define retirement, in particular, later and more flexible retirement. Part of the reason is that longer healthy life combined with a constant or declining retirement age creates obvious problems paying for pensions. The solution is equally obvious. Pensionable age should rise in a rational way as life expectancy increases. The original design of pensions in the nineteenth century set a fixed retirement age. If, instead, they had related retirement age to life expectancy, we would not have a pensions "crisis" today. The problem of paying for pensions is largely the result of rising life expect- 
ancy with a fixed retirement age. The argument for later retirement is all the stronger because many people enjoy their work and may not want to retire, not least because jobs today are generally less physically demanding than in the past.

As well as being later, retirement should be more flexible. When retirement was invented someone aged 65 was old and infirm, and hindered the productivity of younger workers. So the purpose was to get rid off unproductive older workers, so it made sense for retirement to be mandatory and complete. Since then, however, people are living longer, and countries have got richer, so that we can afford to give people a period of leisure at the end of their working lives. That, however, means that the purpose of retirement has changed, so that it is right to allow people choice and flexibility over how they move from full time work to full retirement. Flexible retirement would be good policy even if there were no problem in paying for pensions.

The United States is in the process of increasing its retirement age from 65 to 67 . Norway already has a retirement age of 67. In the UK, the Pensions Commission handled the politics superbly, and it has been announced that retirement age will rise from 65 to 66 in 2024, and by another year in 2034. The UK illustrates that it is an error, both in economic and political terms, to make sudden changes. Because the Pensions Commission avoided that mistake, its chairman could go on television on the day the report was published and say: "If you are over fifty, this does not affect you. If you are over forty, you will have to work an extra year." So any increase in retirement age should be announced as soon as possible but should take effect only some significant time in the future. Because the politics of change were handled well in Britain, it is now politically possible to have a sensible discussion about retirement age.

\subsection{Consumption smoothing: Learning from the USA}

A third policy direction is a lesson from the Thrift Savings Plan, a pension plan for federal civil servants in the United States (www.tsp.gov). The design of the pension draws on lessons from the economics of information and from behavioural economics.

LESSONS FROM INFORMATION ECONOMICS. Choice and competition are beneficial when consumers are well informed. A large part of the transition from communism was to bring in private markets to create competition and to give consumers choice. That was the right policy in most areas. But where consumers are badly informed, choice and competition may not maximize consumer welfare. In the case of pensions, there is considerable evidence that consumers are extraordinarily badly informed. A survey found that 50 per cent of Americans did not know the difference between a stock and a bond. That is a very basic distinction. How can a person choose a private pension provider if he or she does not know that basic point? ${ }^{3}$

3 Bonds are financial securities that represent a loan from the buyer of the bond (the bondholder) to the seller. Bonds normally specify a date on which the bondholder will be repaid (the redemption or maturity date) and an interest payment stated as a cash payment (dollars, Euros, etc.) per year. Stocks (also called equities or shares) are financial securities that represent ownership of a fraction of a corporation. A corporation sells stock as a way of financing its investment and may pay dividends to stockholders. If the corporation 
Secondly, most people do not understand the need to shift from equities to bonds as they age, if they hold an individual account. In a sad news item on the BBC about a year ago, an elderly car worker in Detroit said that he had lost 37 per cent of his pension savings in the previous two weeks. My reaction was -- what crazy pension system would allow a worker close to retirement still to be in the stock market, rather than having over the years come out of equities into government bonds.

A third area of imperfect information is that very few people realise the significance of administrative charges. The only piece of advice I ever give people on pensions is to look at the administrative charges. If a pension fund has an annual management charge of one per cent, then over a full working life, a person's accumulation will be 20 per cent lower because of that charge than otherwise, and hence the pension 20 per cent smaller.

LESSONS FROM BEHAVIOURAL ECONOMICS. Simple economic theory predicts that people act rationally, so they will voluntarily save for their old age and, when they retire, will voluntarily buy an annuity. What actually happens, first, is procrastination. People delay saving, or do not save, or do not save enough. A second problem is inertia - people stay where they are. In theory, it should make no difference whether a person has a choice between opting into a pension system or whether he or she is put in to the system automatically and can choose to opt out. But there is powerful evidence that with automatic enrolment many more people stay in the pension system. A third problem is immobilisation. If a person has to make a choice, particularly in an area which he or she does not understand, the likely result is to do nothing. Thus, for example, a Swedish worker has to choose a private pension provider from 785 private pension funds; most of them do not make a choice. Thus there are large conflicts, between what simple economic theory predicts and what actually happens. And behavioural economics helps to explain why.

Experimental evidence shows that people take a short run view when faced with an immediate decision. The experiment they designed worked as follows: as you came into the conference this morning, you signed up for your snack for next week's conference, choosing between fruit salad, which you know is healthy, or a bar of chocolate. In the experiment, two thirds of the participants signed up for the fruit salad next week and one third for chocolate. But as they came in to the hall, there was fruit salad and chocolate, and two thirds of the participants chose the chocolate. Thus people are rational for the future but not for the present; but of course when the future arrives, it becomes the present so participants carry on eating chocolate. We know this from our own lives: the time to start dieting to lose weight is not today, given work pressures and deadlines. The time to stop smoking is not now - this is a tense time of year, the weather is bad, you are underslept etc. So, the time to start dieting or give up smoking is tomorrow, but when tomorrow comes, there is always some reason to postpone.

Again, we know why we react this way. There have been studies of the brain, asking people experimental questions while they are under a CAT scanner. We know that there are

flourishes, the value of its stock rises, resulting in a capital gain to stockholders. If it goes bankrupt, the value of its stock is based on whatever value remains in the corporation after its creditors have been paid. In short, stocks represent a title to ownership, in contrast with bonds which are a form of loan. 
different parts of the brain: the mesolimbic is the oldest part, the animal bit, the survival instinct, this may be the last meal I'll ever eat; the pre-frontal cortex is a much newer part of the brain; that is the part that is patient and rational; this is rational economic man and woman. And we know just by looking at ourselves that life is a constant battle between the two parts. The clinical evidence shows that the mesolimbic system makes short-term decisions and the pre-frontal cortex longer-term decisions, so it is hard wired into us that we tend to make short-run decisions that are not compatible with long-run rationality. These results call into question the simple economic model that predicts that we will be long-run rational maximisers and save voluntarily for old age.

IMPLICATIONS. What does this tell us about pension design?

- It is useful to make membership mandatory or to use automatic enrolment.

- In sharp contrast with conventional theory, keep choice simple: in the context of pensions, it is desirable to offer highly constrained choice as a deliberate and welfare enhancing design feature.

- Design a good default option for people who make no choice; that default option should include life-cycle profiling, whereby young people's savings are mainly in the stock market and, as a person moves towards retirement, his/her assets come out of the stock market into government bonds.

- As regards administration, it is desirable to decouple account management, the back office tasks, from the investment decision, and to centralize all record keeping to keep administrative costs down.

The US Thrift Savings Plan does exactly those things. It was initially voluntary for federal civil servants but now has automatic enrolment. Workers choose from about five funds: an equities fund, a government bonds fund, a corporate bonds fund, a global equities fund, etc. There is centralized account administration to keep costs low, and wholesale management of funds in the private sector. This arrangement simplifies the choice for workers, respecting information constraints, and it keeps administrative costs low. The UK is about to introduce a system of personal accounts that is very similar.

Thus if policy makers in a country think that having funded individual accounts is a good idea, the message from the Thrift Savings Plan is that it is possible to have such accounts, but they do not necessarily have to give individuals a wide range of choice. Given behavioural problems and information problems, choice and competition in this part of the economy may not be a good idea.

\subsection{Consumption smoothing: Learning from Sweden}

The Thrift Savings Plan approach is one way of organizing consumption smoothing. Another is that adopted in Sweden. The essence of the Swedish system is the idea of notional defined contributions. In such an arrangement you, as Czech citizens, pay social security contributions to the government. The government uses those contributions this year mostly to pay for this year's pensions, so what we are discussing is a pay-as-you-go system. The government keeps a record of your contributions and it attributes to your notional record each year a notional interest rate, so that when you retire you have a notional accumulation which is converted into an annuity. 
Thus the pension a person gets bears an exact relationship to his contributions over his working life. The arrangement has - much in common with individual funded accounts, but is not fully funded. Such schemes can have a range of advantages. They are simple from the point of view of the worker, they are centrally administered and so have low administrative costs. They avoid much of the risk of funded individual accounts, because they avoid the volatility of capital markets. Indeed, Peter Diamond and I have argued that in the context of China, individual accounts make a lot of sense, but do not have to be funded individual accounts; instead, we argued for notional accounts. Countries with notional defined contribution pensions include Sweden, Poland and Latvia.

\section{Conclusion}

Let me repeat: there is no single best pension system. What is optimal will differ across countries and over time. Pensions systems look different in different countries; this is as it should be. The system in the Netherlands is different from the system in Canada, which is different from the system in Chile, which is different from the system in France, and that is not a problem. But, that said, the four policy directions discussed above are potentially widely useful.

The range of variation in different countries is wide. Some countries focus mainly on consumption smoothing. Singapore has a state administered provident fund, which is really a savings scheme, so Singapore gives low weight to poverty relief. Other countries focus heavily on poverty relief through a non-contributory pension. New Zealand has a generous non-contributory pension and, till very recently, the consumption smoothing element was voluntary. Countries like the Netherlands pursue both objectives. The Netherlands has non-contributory pensions plus funded occupational pensions. Chile had a system of individually funded accounts with rather limited poverty relief. Policy makers there recognised the problem, and in 2008 introduced a non-contributory pension alongside their system of individual funded accounts.

Finally, the "so what" question - why does this matter? Pensions matter for obvious reasons and for less obvious ones. Pensions affect the quality of life of hundreds of millions of older citizens and, as they look to their future, hundreds of millions of workers. Thus pensions matter enormously to the quality of people's lives.

Pensions also matter for national economic performance. Earlier today we heard the Governor of the Central Bank and the Minister of Finance worrying about the size of contributions necessary to finance pensions in the Czech Republic. If taxes and contributions are too high, they can harm growth rates. So pensions need to be designed so that they do not harm growth.

My final point is slightly fanciful, but only slightly. China does not yet have a robust pension system that covers most of the population. If you are a Chinese worker and there is very little pension and little medical insurance, what are you going to do? You are going to save like crazy. Economists call this precautionary saving. China is currently saving a staggering 52 per cent of GDP. And what happened to those savings? Answer: they financed the US trade deficit. So, credit in the United States was cheap. US banks had money to lend, and lent it; and therein lies one of the roots of the financial crisis that led to the cur- 
rent economic crisis. I am not saying the financial crisis was all the fault of the Chinese for not having a good pension system. But I am saying that pensions are an important part of economies, and economies are interconnected within a country and across countries, so that one of the contributory elements of the current economic crisis is that China does not have a robust pension system.

So, the bottom line is that pensions matter. They matter for social policy reasons; they matter for economic reasons; they matter for European integration and labour mobility. So I am delighted, you have chosen this as the topic of today's conference and I wish you well, both for the rest of the conference and for pension reform in the Czech Republic on what is, as I say, the twentieth anniversary of my first trip to the region.

Thank you very much.

\section{References}

BARR, N.; DIAMOND, P. (2008). Reforming pensions: Principles and policy choices, New York and Oxford: OUP.

BARR, N.; DIAMOND, P. (2009). Reforming pensions: Principles, analytical errors and policy directions, International Social Security Review, Vol. 62, No. 2, 2009, pp. 5-29 (also in French, German and Spanish).

BARR, N.; DIAMOND, P. (2010). Pension reform: A Short Guide, New York and Oxford: OUP. UK PENSIONS COMMISSION. (2004). Pensions: Challenges and Choices: The First Report of the Pensions Commission, London: TSO, http://www.pensionscommission.org.uk

UK PENSIONS COMMISSION. (2005). A New Pension Settlement for the Twenty-First Century: Second Report of the Pensions Commission, London: TSO, 2005, http://www.pensionscommission.org.uk

US THRIFT SAVINGS PLAN (http://www.tsp.gov)

\section{Contact address/Kontaktní adresa \\ Nicholas Barr}

Professor of Public Economics (European Institute) London School of Economics and Political Science N.Barr@lse.ac.uk 